\title{
Advanced Technologies for Landslides (WCoE 2014-2017, IPL-196, IPL-198)
}

\author{
Nicola Casagli, Veronica Tofani, Filippo Catani, Sandro Moretti, \\ Riccardo Fanti, and Giovanni Gigli
}

\begin{abstract}
The Earth Sciences Department of the University of Firenze (DST-UNIFI) since 2002 has been a member of the International Consortium on Landslides (ICL) and three times it has been awarded status as a World Centre of Excellence (WCoE) for Landslide Risk Reduction (2008-2010, 2011-2013, 2014-2016). Since 2016, DST-UNIFI has established a UNESCO Chair on Prevention and sustainable management of geo-hydrological hazards. In this paper we describe the activities carried out by DST-UNIFI as a member of ICL and as WCoE in the framework of landslide risk reduction, landslide prevention and management.
\end{abstract}

\section{Keywords}

Italy $\bullet$ Landslides $\bullet$ Monitoring $\bullet$ Remote sensing $\bullet$ Landslide prediction $\bullet$ Multi-sensors drone

\section{Introduction}

The Earth Sciences Department of the University of Firenze (DST-UNIFI) has, since 2002, been a member of the International Consortium on Landslides (ICL) and it has been awarded status as a World Centre of Excellence (WCoE) for Landslide Risk Reduction three times (2008-2010, 20112013, 2014-2016).

\footnotetext{
N. Casagli $(\bowtie) \cdot$ V. Tofani - F. Catani $\cdot$ S. Moretti $\cdot$ R. Fanti . G. Gigli

Department of Earth Sciences, University of Firenze, Via La Pira

4, 50212 Florence, Italy

e-mail: nicola.casagli@unifi.it

V. Tofani

e-mail: veronica.tofani@unifi.it

F. Catani

e-mail: filippo.catani@unifi.it

S. Moretti

e-mail: sandro.moretti@unifi.it

R. Fanti

e-mail: riccardo.fanti@unifi.it

G. Gigli

e-mail: giovanni.gigli@unifi.it
}

DST-UNIFI is one of the largest centres for scientific and technological services on geohazards in Italy, and currently comprises 46 full-time employees. The group participates in research and technological development projects in several areas of the world, often in active collaboration with international, national and regional organizations and agencies. The main objective of the group is to focus on landslide studies at all scales, with an emphasis that in recent years has moved towards the application and development of new technologies for landslide disaster prevention, monitoring and early warning, with a special emphasis on remote sensing and regional landslide forecasting models.

In June 2016, the DST-UNIFI successfully established an UNESCO Chair on prevention and sustainable management of geo-hydrological hazards. Since 2002 DST-UNIFI has coordinated or has been involved in several ICL/IPL projects.

In this paper we describe the research activities carried out by DST-UNIFI as WCoE (2014-2017) and the research outcomes of two ongoing ICL/IPL projects (IPL196: Development and applications of a multi-sensors drone for geohazards monitoring and mapping, IPL198: Multi-scale 
rainfall triggering models for Early Warning of Landslides (MUSE)) led by DST-UNIFI.

\section{WCoE (2014-2017) Activities}

\section{Research Activities}

The objective of the WCoE has been to develop new methodologies and advanced technologies for landslide risk reduction. DST-UNIFI has carried out research and development for the prevention and management of landslides, in order to support policies and actions of risk reduction. In particular, research activity has focused on the development of advanced methodologies useful for applications to landslides as such and has been structured in the following three work packages (WPs):

- $\mathrm{WP}_{1}$ : Ground-based SAR interferometry for landslide monitoring and development of reliable procedures and technologies for early warning.

- $\mathrm{WP}_{2}$ : EO (Earth Observation) data and technology to detect, map, monitor and forecast ground deformations.

- $\mathrm{WP}_{3}$ : Coupling of short-term weather forecasting with geotechnical modeling for shallow landslide prediction.

Concerning $\mathrm{WP}_{1}$ the DST-UNIFI performed monitoring activities of unstable slopes in order to estimate the deformational evolution of the landslide events (in space and time) and to implement the most suitable operational early warning systems (EWS) based on different critical situations (Carlà et al. 2016; Agostini et al. 2014; Bardi et al. 2014; Intrieri et al. 2013). Several sites have been monitored in Italy (Fig. 1 reports the example of the Calatabiano landslide, which occurred in November 2016), all of them were monitored using advanced sensors and portable instruments such as ground-based synthetic aperture radar interferometer (GB-InSAR), terrestrial laser scanning (LIDAR), satellite interferometry (PS-InSAR), GPS antennas and infrared thermography and traditional instrumentation (e.g., strain gauges, inclinometers, piezometers) (Fig. 1) (Nocentini et al. 2015; Margottini et al. 2015; Di Traglia 2014a, b; Gigli et al. 2014a, b).

Each time the best-integrated uses and synergetic approaches were evaluated. Using all these monitoring activities, the DST-UNIFI performed and validated a rapid procedure (called Landslide Triage) for the unambiguous assessment of landslide risk through a specific evaluation sheet, which considers all the hazardous conditions associated with landslides.

The goal of this procedure is to assign, as quickly and objectively as possible, a level of criticality, which allows speeding up the selection of actions to take.
In $\mathrm{WP}_{2}$ the research was focused on the development of a satellite surveillance system, exploiting satellite data for the identification, mapping, monitoring and analysis of risk scenarios associated with landslides, from local to regional scale (Tofani et al. 2017; Bianchini et al. 2014; Lu et al. 2014). Its implementation was carried out by:

- The application of satellite radar interferometry in monitoring and emergency support to areas affected by hydro-geologic instabilities threatening or involving the population and its activities;

- The creation of geodatabases for each critical area, arranged to contain all the available data (both optical and radar) and new specific calculations in a homogenized framework;

- The integration of susceptibility models and interferometric data acquired by the satellite platform;

- Stitching (merged analysis) between RADARSAT-1 and RADARSAT-2 images in order to ensure continuity of data monitoring.

Through these issues we tried to use satellite data to increase the number, quality and accuracy of products that can be readily utilized to reduce risk in areas affected by slope instability. Some of these products are: (i) ground deformation velocity maps, (ii) damage assessments, (iii) susceptibility and (iv) risk zonation maps (Ciampalini et al. 2016a).

In particular, the development of a geodatabase dedicated to landslides allowed us to include different types of data such as pre-existing inventories (ancillary records), auxiliary data (e.g., thematic maps, DEMs, VHR optical photos) and new remote sensing SAR (Synthetic Aperture Radar) data (e.g. from COSMO-SkyMed constellation) and subsequently to properly link them. This makes possible the generation of high quality map products at various levels of specificity (Bianchini et al. 2016; Ciampalini et al. 2016b; Raspini et al. 2015; Tofani et al. 2014; Del Ventisette et al. 2014).

On the other hand, using remotely sensed data acquired through different SAR satellites (e.g., ERS1/2, RADARSAT1/2, ENVISAT, COSMO-SkyMed), the slope deformations of the study areas were monitored in order to promptly undertake alert procedures and to address suitable countermeasures in case of high criticalities. The long time series of displacement provided by the Persistent Scatterer SAR Interferometry (PSInSAR) technique allowed us to define the most critical unstable sectors, to update the extension of landsliding phenomena and to redefine their state of activity (Fig. 2). This was possible by comparing the ground deformation velocities measured at different times over the same target area. Usability of remote sensing data, comprising satellite, optical and ground-based data (e.g., 
Fig. 1 Calatabiano landslide occurred in October 2016 in Soukhern Italy and was caused by a damaged water pipe. An integrated monitoring system has been installed just after the event. a study area and landslide. b Displacements map derived from GB-Insar measurements from $11 / 11 / 2015$ to $31 / 12 / 2015$. (modified from Lombardi et al. 2017)

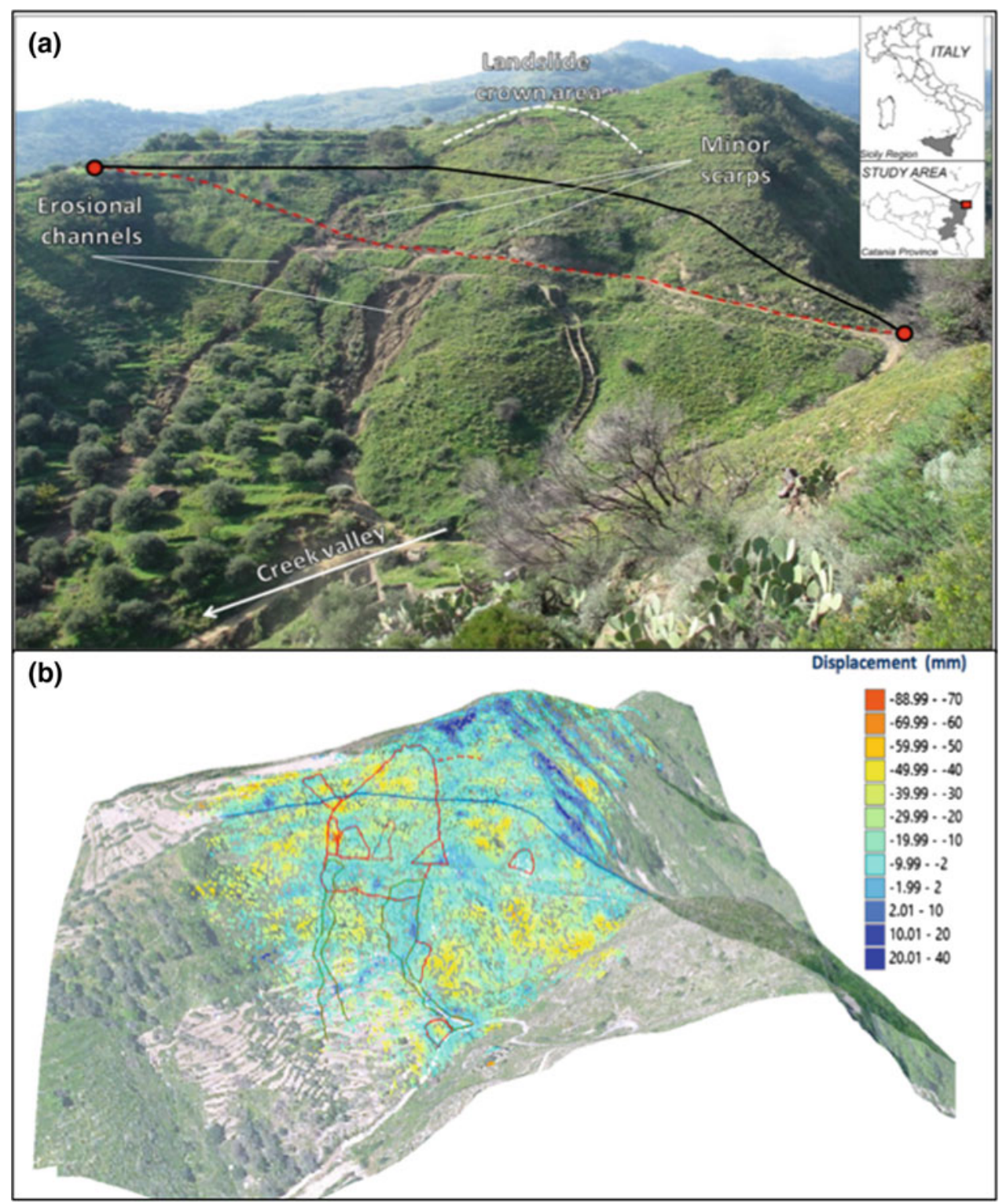

GB-InSAR) was also exploited during all the phases of the emergency management cycle: prevention, crisis, and post-crisis (Raspini et al. 2014).

In $\mathrm{WP}_{3}$ the research activities include the development of a physically-based model, called HIRESSS (Rossi et al. 2013; Mercogliano et al. 2013), for the real time prediction of shallow landslides induced by rain on large areas, predictive statistical models (SIGMA and MACUMBA models) (Martelloni et al. 2012; Lagomarsino et al. 2013; Segoni et al. 2014a, b; Rosi et al. 2016) based on the identification of rainfall thresholds for triggering landslides, and a nowcasting system which includes a forecasting and alert system valid at the national level for landslides with fast kinematics (not monitorable by satellite).
During the last year, the system of collection, storage and querying of meteorological data was implemented with the creation of an efficient database. The two statistical models have been extended to the whole national territory in order to find a peculiar rainfall threshold for the landslides initiation in each alert zone (137) outlined by the Italian Civil Protection. In particular, the thresholds calculated by the software MACUMBA were essentially improved by applying the new rainfall collecting platform created, then they were subjected to a rigid manual quality control (Segoni et al. 2014c).

The integrated nowcasting system is mainly formed by two levels of forecasting: one is managed by the MACUMBA model in its real-time and one is derived from the output of the HIRESSS physically based model (Fig. 3). 

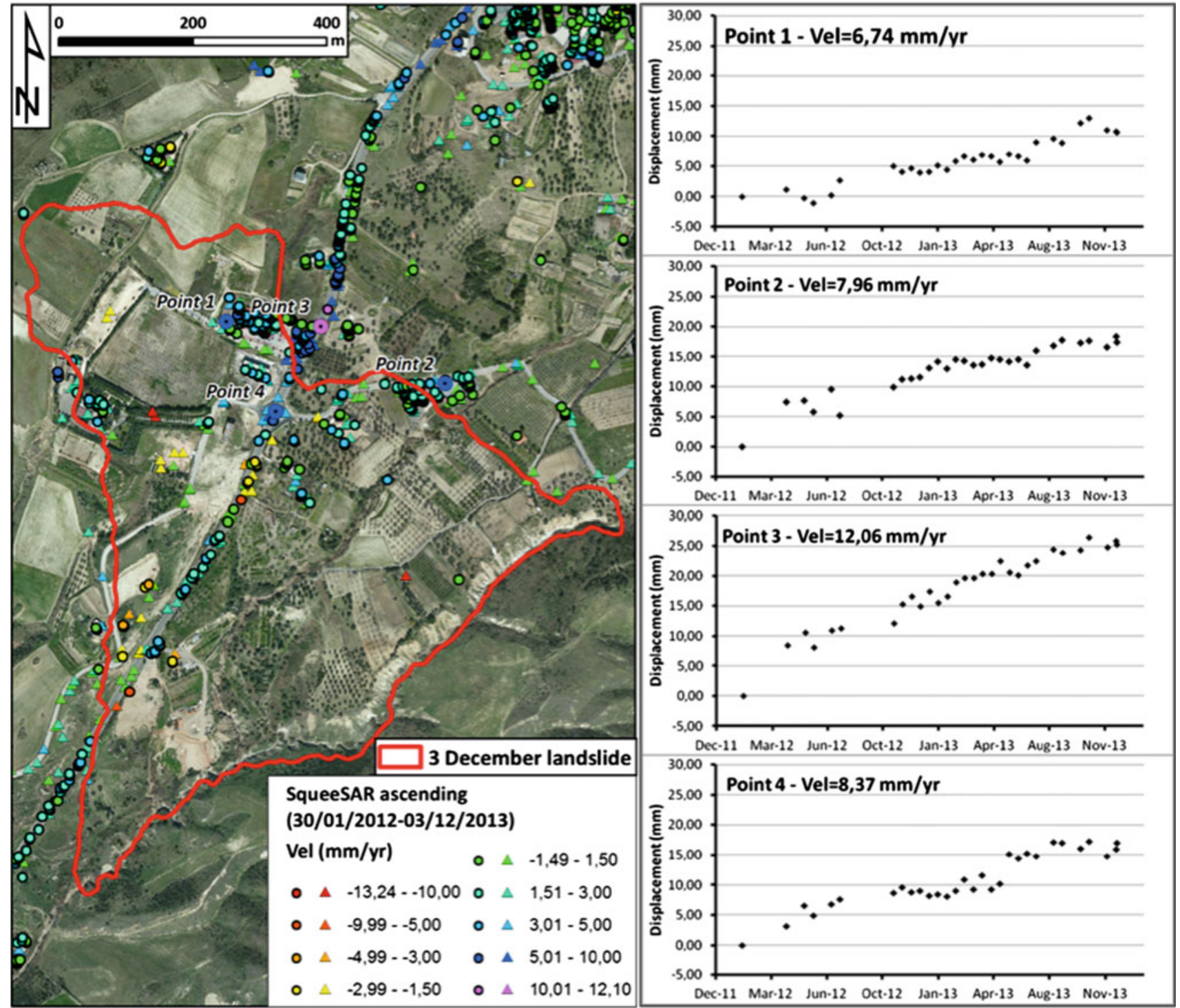

Fig. 2 The Montescaglioso landslides (Basilicata Region, southern Italy) occurred on 3 December 2013, caused by prolonged and intense rainfalls and rapid slope failure, and producing a ground displacement

\section{Capacity Development and International Cooperation}

In March 2015, the DST-UNIFI successfully applied for an UNESCO Chair on prevention and sustainable management of geo-hydrological hazards (www.unesco-geohazards.unifi. it).

The mission of the Chair is to promote research and development for the prevention and management of geo-hydrological hazards, in order to support policies and actions of risk reduction. of several meters. In the figure is an analysis of the pre-event SqueeSAR data (Raspini et al. 2015)

In particular, the Chair aims at the implementation of the Sendai Partnership 2015B2025, launched at the World Conference on Disaster Risk Reduction (WCDRR) in Sendai by the International Strategy for Disaster Reduction (ISDR) and by the International Consortium on Landslides (ICL), for global promotion of understanding and reducing landslide disaster risk, which was also signed by UNESCO and the Italian Government, among other partners and UN organizations. Applied research for a Safer Society will be the main keyword of the Chair.

The specific objectives of the Chair are: 
Fig. 3 Block diagram illustrating the mode operation of the integrated nowcast system

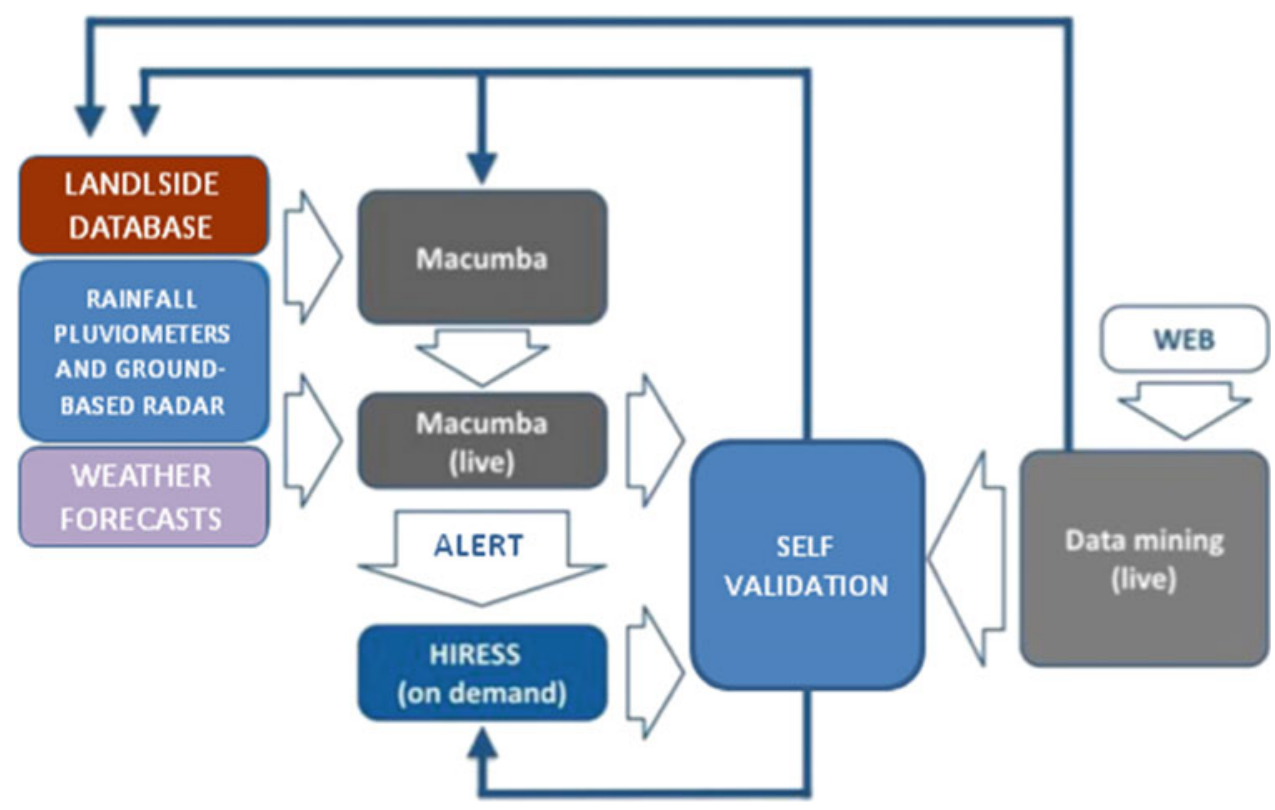

(1) to promote the development of innovative technologies for the prevention and mitigation of geo-hydrological hazards;

(2) to develop tools and procedures for supporting risk reduction policies and emergency management for the safety of human life;

(3) to promote the protection of cultural heritage threatened by geo-hydrological hazards;

(4) to promote research at an international level by offering scientific facilities to postgraduate students and visiting researchers.

Several types of activities will be carried out in the framework of the Chair, such as a postgraduate teaching programme, short-term training, research, a visiting professorship, scholarships, and institutional development. The target beneficiaries will be students, professionals, and governmental organizations.

\section{ICL/IPL Projects Research Activities}

DST-UNIFI is currently involved into two IPL projects, namely:

- IPL 196: Development and applications of a multi-sensors drone for geohazards monitoring and mapping

- IPL198: Multi-scale rainfall triggering models for Early Warning of Landslides (MUSE).

\section{Development and Applications of a Multi-sensors Drone for Geohazards Monitoring and Mapping (IPL 196)}

The objective of the proposed project is to test the applicability of a multi-sensors drone to the mapping and monitoring of geohazards. The project has two specific objectives: (i) development of the drone, sensors, safety and automation and (ii) application of the drone as a platform for integrated sensors (multispectral sensor, visible light camera, infrared camera and LIDAR) for the mapping and monitoring of geohazards.

The project activities are related to the two work packages:

$\mathrm{WP}_{1}$ : Development of the multicopter drone, sensors, safety and automation.

$\mathrm{WP}_{2}$ : Application of the multi-sensors drone for rapid mapping, 3D surface reconstruction, monitoring.

In $\mathrm{WP}_{1}$ the activities have concerned the research and development of the chassis and the flight model to improve flight range and transportable instruments weight limits. Recently a new chassis drone (SATURN) has been designed, after over $70 \mathrm{~h}$ of flight of the first prototype. This new chassis is stiffer and more resistant, while maintaining the same weight as the previous one, ensuring more stability and precision during flight, even with heavier instruments (Fig. 4). 


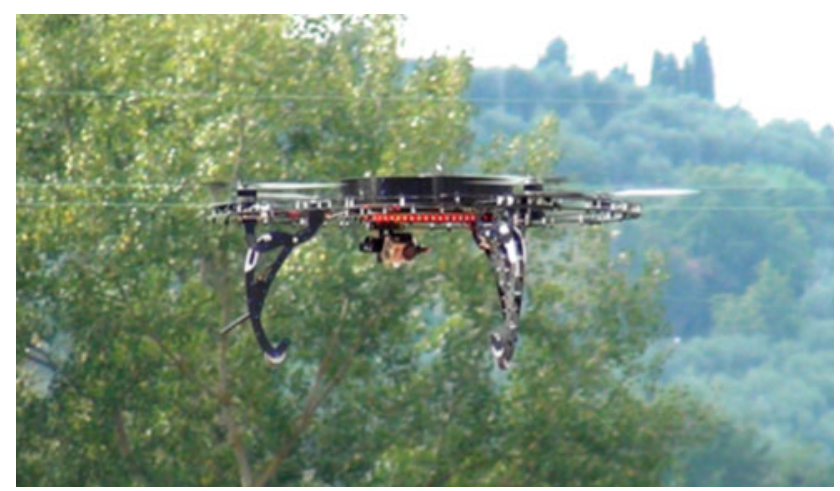

Fig. 4 SATURN drone

In order to avoid damage or loss of costly instruments after a possible electrical failure, a redundant safety system has been developed. This system includes redundant flight electronics, and in particular we focused on the reliability of the power supply and the GPS signal.

The multicopter drone has been equipped with a visible light and a multispectral NIR camera, while a very light hyperspectral sensor (visible and near infrared) has been specifically designed to be installed on the drone and is currently under development.

$\mathrm{WP}_{2}$ has mainly focused on the application of multi-sensor drones to selected case studies and on the validation of the multi-sensor drone acquisitions with data from ground-based instrumentation for selected test sites. In particular the activity has dealt with the application of the multicopter drone equipped with visible light camera for mapping and 3D surface reconstruction of landslides. 3D surface reconstruction with optical sensors has been carried out during multiple campaigns in order to define the volume variation in time.

The first application of the drone is in the village of Ricasoli, in Tuscany (Italy), which is strongly affected by landslide activity. In this site three survey campaigns have been carried out to determine the capability of this rising technology to characterize and to monitor landslides. High temporal frequency DEMs have been derived by the DST drone in Ricasoli village. In order to obtain a detailed reconstruction of the topography of the site, three aerial photogrammetric survey were conducted on July 2015, March 2016 and April 2016, the second and the third ones being conducted after two landslide events.

The DEMs derived from the three photogrammetric surveys were analyzed and compared with each other in order to detect any possible area affected by slope deforming processes. The volume mobilized among the three acquisitions was also computed (Fig. 5). Further information on the analysis and comparison of DEMs derived from the drone surveys of Ricasoli landslides can be found in Tanteri et al. (2017).

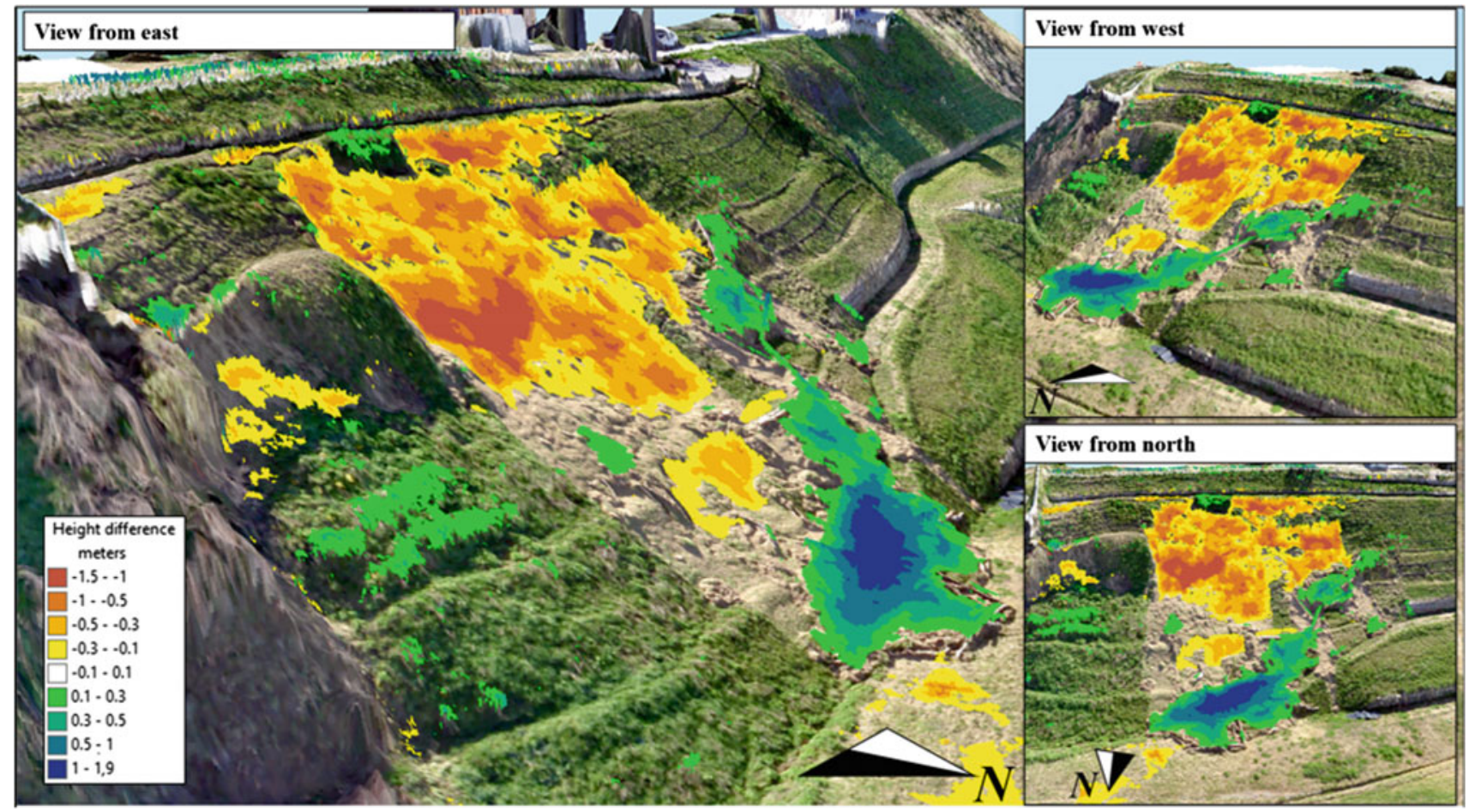

Fig. 5 Elevation difference between the second (March 2016) and first (July 2015) drone photogrammetric surveys in Ricasoli village 


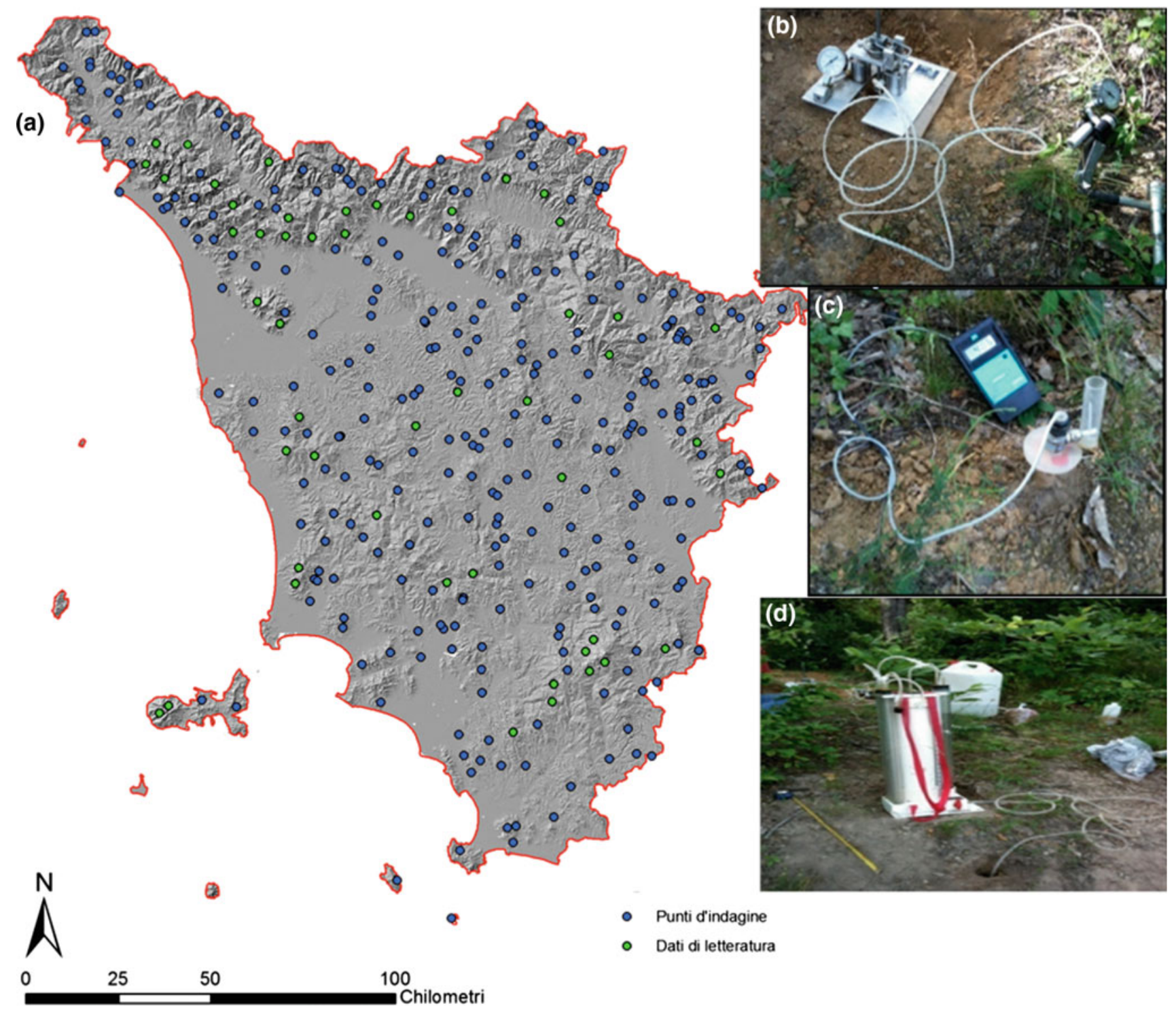

Fig. 6 a Distribution of survey points (blue and green) in Tuscany (Italy), b Borehole Shear Test elevation difference, c Tensiometer, d constant-head well permeameter Amoozemeter

\section{Multi-scale Rainfall Triggering Models for Early Warning of Landslides (MUSE) (IPL 198)}

The main objective of this IPL project is the enhancement of knowledge and methods to integrate landslide prediction models at different scales to build an effective operational multi-scale system for real-time early warning of rainfall-triggered mass movements. The project is structured into two work packages:

$\mathrm{WP}_{1}$ : Soil properties variability study.

$\mathrm{WP}_{2}$ : Analysis and integration of rainfall data and rainfall forecasts.
In $\mathrm{WP}_{1}$ the activity has focused on the characterization of geotechnical properties of the soil cover of the hillslopes in Tuscany (Central Italy) in order to improve the reliability of deterministic model output such as the HIRESSS (HIgh REsolution Slope Stability Simulator; Rossi et al. 2013). This software makes use of a Monte Carlo simulation technique to manage the uncertainty typical of geotechnical and hydrological input parameters, which is a common weakness of deterministic models. Uncertainty in the geotechnical input parameter values can be solved by using a frequency distribution model for the parameters. This helps to restrict the number of in situ and laboratory measurements and is crucial for reducing computation time within 
HIRESSS and other similar distributed numerical models at the basin scale (Fig. 6).

In the Tuscany region $\left(22,994 \mathrm{~km}^{2}\right) 130$ survey points were selected. The following in situ measurements were performed at each survey point (Fig. 6): (i) shear strength under natural conditions by means of a Borehole Shear Test (Lutenegger and Halberg 1981) jointly with the (ii) matric suction obtained with a tensiometer, (iii) saturated hydraulic conductivity (ksat) by means of a constant-head well permeameter Amoozemeter (Amoozegar 1989) and (iv) sampling of two aliquots ( $\sim 2 \mathrm{~kg}$ each) of the material for laboratory tests. The Borehole Shear Test allows the measure of shear strength parameters under natural in situ conditions.

In addition to the in situ measures, the grain size distribution and the relationships of phases (porosity, dry unit weight $\gamma_{d}$ ) are determined in the laboratory following the ASTM (American Society for Testing and Materials) recommendations (ASTM D422-63 2007, ASTM D2217-85 1998 and ASTM D-4318 2010).

The geotechnical parameters measured have been statistically analyzed and linked to the main lithologies of the bedrock in order to define the input hydrological and geotechnical parameters for the HIRESSS model. The HIRESSS code has been applied in a selected study area located in Northern Tuscany in order to test the performance of the models with the measured geotechnical and hydrological parameters. Further applications will be carried out to test the sensitivity of the model to the variation of the model results (Tofani et al. in review).

In $\mathrm{WP}_{2}$ the system of collection, storage and querying of meteorological data was implemented with the creation of an efficient database that allows the storage of both historical records and real-time data coming from the National Radar Network and also from the rainfall network belonging to the National Civil Protection. In this way, new data can be continuously added to the already stored files in the same format through the same indexing procedures. Therefore, this reference platform was necessary to transfer the physically-based model (HIRESSS) from first an experimental scientific software to an operative system for real-time applications at a regional scale.

\section{References}

Agostini A, Tofani V, Nolesini T, Gigli G, Tanteri L, Rosi A, Cardellini S, Casagli N (2014) A new appraisal of the Ancona landslide based on geotechnical investigations and stability modelling. Q J Eng GeolHydrogeol 47(1):29-43. doi:10.1144/ qjegh2013-028

Amoozegar A (1989) Compact constant head permeameter for measuring saturated hydraulic conductivity of the vadose zone. Soil Sci Soc Am J 53:1356-1361

Bardi F, Frodella W, Ciampalini A, Bianchini S, Del Ventisette C, Gigli G, Fanti R, Moretti S, Basile G, Casagli N (2014) Integration between ground based and satellite SAR data in landslide mapping:
The San Fratello case study. Geomorphology 223:45-60. doi:10. 1016/j.geomorph.2014.06.025

Bianchini S, Ciampalini A, Raspini F, Bardi F, Di Traglia F, Moretti S, Casagli N (2014) Multi-temporal evaluation of landslide movements and impacts on buildings in San Fratello (Italy) by means of C-band and X-band PSI data. Pure appl Geophys 172(11):30433065. doi:10.1007/s00024-014-0839-2

Bianchini S, Raspini F, Ciampalini A, Lagomarsino D, Bianchi M, Bellotti F, Casagli N (2016) Mapping landslide phenomena in landlocked developing countries by means of satellite remote sensing data: the case of Dilijan (Armenia) area. Geomatics, Natural Hazards and Risk, pp 1-17

Carlà T, Intrieri E, Di Traglia F, Nolesini T, Gigli G, Casagli N (2016) Guidelines on the use of inverse velocity method as a tool for setting alarm thresholds and forecasting landslides and structure collapses. Landslides. doi:10.1007/s10346-016-0731-5

Ciampalini A, Raspini F, Lagomarsino D, Catani F, Casagli N (2016a) Landslide susceptibility map refinement using PSInSAR data. Remote Sens Environ 184:302-315

Ciampalini A, Raspini F, Frodella W, Bardi F, Bianchini S, Moretti S (2016b) The effectiveness of high-resolution LiDAR data combined with PSInSAR data in landslide study. Landslides 13(2):399-410. doi:10.1007/s10346-015-0663-5

Del Ventisette C, Righini G, Moretti S, Casagli N (2014) Multitemporal landslides inventory map updating using spaceborne SAR analysis. Int J Appl Earth Obs Geoinf 30(1):238-246. doi:10.1016/j.jag. 2014.02.008

Di Traglia F, Cauchie L, Casagli N, Saccorotti G (2014a) Decrypting geophysical signals at Stromboli Volcano (Italy): Integration of seismic and Ground-Based InSAR displacement data. Geophys Res Lett 41(8):2753-2761. doi:10.1002/2014GL059824

Di Traglia F, Intrieri E, Nolesini T, Bardi F, Del Ventisette C, Ferrigno F, Frangioni S, Frodella W, Gigli G, Lotti A, Tacconi Stefanelli C, Tanteri L, Leva D, Casagli N (2014b) The ground-based InSAR monitoring system at Stromboli volcano: linking changes in displacement rate and intensity of persistent volcanic activity. Bulletin of Volcanology, vol 76(2). doi:10.1007/ s00445-013-0786-2

Intrieri E, Gigli G, Casagli N, Nadim F (2013) Brief communication landslide early warning system: toolbox and general concepts. Nat Hazards Earth Syst Sci 13(1):85-90. doi:10.5194/nhess-13-85-2013

Gigli G, Frodella W, Garfagnoli F, Morelli S, Mugnai F, Menna F, Casagli N (2014a) 3-D geomechanical rock mass characterization for the evaluation of rockslide susceptibility scenarios. Landslides 11(1):131-140. doi:10.1007/s10346-013-0424-2

Gigli G, Morelli S, Fornera S, Casagli N (2014b) Terrestrial laser scanner and geomechanical surveys for the rapid evaluation of rock fall susceptibility scenarios. Landslides, vol 11(1). doi:10.1007/ s10346-012-0374-0

Lagomarsino D, Segoni S, Fanti R, Catani F (2013) Updating and tuning a regional-scale landslide early warning system. Landslides 10(1):91-97. doi:10.1007/s10346-012-0376-y

Lombardi L, Nocentini M, Frodella W, Nolesini T, Bardi F, Intrieri E, Carlà T, Solari L, Dotta G, Federica Ferrigno F, Casagli N (2017) The Calatabiano landslide (Southern Italy): preliminary GB-InSAR monitoring data and remote 3D mapping. Landslides J 14(2):685-696

Lu P, Catani F, Tofani V, Casagli N (2014) Quantitative hazard and risk assessment for slow-moving landslides from Persistent Scatterer Interferometry. Landslides 11(4):685-696. doi:10.1007/s10346-013-0432-2

Lutenegger AJ, Halberg GR (1981) Borehole shear test in geotechnical investigation. Special technical Publ. Am Soc Test Mater 740:566-578

Margottini C, Antidze N, Corominas J, Crosta GB, Frattini P, Gigli G, Giordan D, Iwasaky I, Lollino G, Manconi A, Marinos P, Scavia C, Sonnessa A, Spizzichino D, Vacheishvili N (2015) Landslide hazard, monitoring and conservation strategy for the safeguard of 
Vardzia Byzantine monastery complex. Georgia Landslides 12 (1):193-204

Martelloni G, Segoni S, Fanti R, Catani F (2012) Rainfall thresholds for the forecasting of landslide occurrence at regional scale. Landslides 9(4):485-495. doi:10.1007/s10346-011-0308-28-2

Mercogliano P, Segoni S, Rossi G, Sikorsky B, Tofani V, Schiano P, Catani F, Casagli N (2013) Brief communication "A prototype forecasting chain for rainfall induced shallow landslides". Nat Hazards Earth Syst Scie 13(3):771-777. doi:10.5194/nhess-13-771-2013

Nocentini M, Tofani V, Gigli G, Fidolini F, Casagli N (2015) Modeling debris flows in volcanic terrains for hazard mapping: the case study of Ischia Island (Italy). Landslides. doi:10.1007/s10346-014-0524-7

Raspini F, Moretti S, Fumagalli A, Rucci A, Novali F, Ferretti A, Prati C, Casagli N (2014) The COSMO-SkyMed constellation monitors the Costa Concordia wreck. Remote Sens 6(5):3988 4002. doi: $10.3390 / \mathrm{rs} 6053988$

Raspini F, Ciampalini A, Del Conte S, Lombardi L, Nocentini M, Gigli G, Casagli N (2015) Exploitation of amplitude and phase of satellite SAR images for landslide mapping: the case of Montescaglioso (South Italy). Remote Sens 7(11):14576-14596

Rosi A, Peternel T, Jemec-Auflič M, Komak M, Segoni S, Casagli N (2016) Rainfall thresholds for rainfall-induced landslides in Slovenia. Landslides. doi:10.1007/s10346-016-0733-3

Rossi G, Catani F, Leoni L, Segoni S, Tofani V (2013) HIRESSS: a physically based slope stability simulator for HPC applications. Nat Hazards Earth Syst Sci 13(1):151-166. doi:10.5194/nhess-13-151-2013
Segoni S, Rossi G, Rosi A, Catani F (2014a) Landslides triggered by rainfall: a semi-automated procedure to define consistent intensityduration thresholds. Comput Geosci 63:123-131. doi:10.1016/j. cageo.2013.10.009

Segoni S, Battistini A, Rossi G, Rosi A, Lagomarsino D, Catani F, Moretti S, Casagli N (2014b) Technical Note: An operational landslide early warning system at regional scale based on space-time variable rainfall thresholds. Nat Hazards Earth Syst Sci Discuss 2:6599-6622. doi:10.5194/nhessd-2-6599-2014

Segoni S, Rosi A, Rossi G, Catani F, Casagli N (2014c) Analysing the relationship between rainfalls and landslides to define a mosaic of triggering thresholds for regional scale warning systems. Nat Hazards Earth Syst Sci Discuss 2:2185-2213. doi:10.5194/nhessd2-2185-2014

Tanteri L, Rossi G, Tofani V, Vannocci P, Moretti S, Casagli N (2017a) Multitemporal UAV survey for mass movement detection and monitoring. In: Proceedings of Fourth World Landslide Forum, Ljubljana, Slovenia, May 29-June 2, 2017

Tofani V, Del Ventisette C, Moretti S, Casagli N (2014) Integration of remote sensing techniques for intensity zonation within a landslide area: a case study in the Northern Apennines, Italy. Remote Sens 6 (2):907-924. doi:10.3390/rs6020907

Tofani V, Bicocchi G, Rossi G, Segoni S, D’Ambrosio M, Catani F, Casagli N (2017) Soil characterization for shallow landslides modeling: a case study in the Northern Apennines (Central Italy). Landslides J 14(2):755-770
Open Access This chapter is licensed under the terms of the Creative Commons Attribution 4.0 International License (http:// creativecommons.org/licenses/by/4.0/), which permits use, sharing, adaptation, distribution and reproduction in any medium or format, as long as you give appropriate credit to the original author(s) and the source, provide a link to the Creative Commons license and indicate if changes were made.
The images or other third party material in this chapter are included in the chapter's Creative Commons license, unless indicated otherwise in a credit line to the material. If material is not included in the chapter's Creative Commons license and your intended use is not permitted by statutory regulation or exceeds the permitted use, you will need to obtain permission directly from the copyright holder. 